REVISTA X, Curitiba, volume 13,n.1, p. 6-8, 2018.

Dossiê Especial: Português como Língua Adicional em contextos de minorias:

(co)construindo sentidos a partir das margens

BIZON \& DINIZ (Orgs.)

\title{
NÃO EXISTE A PALAVRA "IMPOSSÍVEL"
}

\section{There is no Word such as "Impossible"}

Eu sou Hanady, mãe síria de dois meninos: o mais velho está com seis anos, e o mais novo, com três. Gostaria de contar para vocês sobre a minha experiência no Brasil.

Nós decidimos vir para cá porque meu marido tinha tentado ir para a Europa pela Turquia, mas sem sucesso. Além disso, a gente achava essa rota muito perigosa, principalmente com duas crianças pequenas. Como meu marido tem dois tios aqui no Brasil, ele pensou que seria mais fácil vir para cá e começar de novo. Ele veio três meses antes de nós. A sua saída foi muito perigosa, porque ele tinha sido convocado pelo exército sírio para lutar na guerra. Por isso, ele teve que sair rapidinho, antes que seu nome fosse divulgado na fronteira e ele não pudesse mais deixar mais o país.

Depois de três meses, eu fui com meus filhos ao Consulado do Brasil em Beirute para pegar o visto. Nós saímos de madrugada, de táxi, para chegar cedo na fila para o visto. Quando chegamos, a fila já estava grande, mas, graças a Deus, dois funcionários que estavam na porta do Consulado me ajudaram a entrar antes dos outros, porque eu estava sozinha com duas crianças muito pequenas. Solicitamos os vistos, deixamos os passaportes e, depois de quinze dias, mais ou menos, pegamos o visto. Depois de dez dias, viajamos de Beirute para Qatar e, de lá, para São Paulo.

O primeiro dia foi no aeroporto, e, na verdade, foi um dia horrível. Aquela foi minha primeira experiência em um país diferente, língua diferente e gente estranha. Vocês não podem imaginar a dificuldade que eu passei só para falar "água". Meu filho de um ano e pouco estava com muita fome, e eu não tinha água para fazer o leite. Meu Deus! Até agora, quando me lembro disso, fico estressada! Então, depois de quinze minutos com o meu filho gritando, finalmente consegui fazer mímica para uma vendedora entender. Vivaaaa! Ganhei! Senti que tinha tido uma grande vitória! Nunca,

\footnotetext{
${ }^{1}$ Professora de francês no CELIN-UFPR. Email: metryhanady@gmail.com.
} 
REVISTA X, Curitiba, volume 13,n.1,p.6-8, 2018.

\section{Dossiê Especial: Português como Língua Adicional em contextos de minorias:}

(co)construindo sentidos a partir das margens

BIZON \& DINIZ (Orgs.)

na minha vida inteira, vou me esquecer desse dia. Quando chegamos em Curitiba, meu marido e os seus tios nos receberam.

Alguns dias depois, graças a pessoas que nos ajudaram, aprendi palavras novas que a gente precisa todo dia como: "bom dia", "obrigada", "boa noite", "boa tarde"... Quem nos ajudou?... O povo brasileiro. Eu gostei do povo daqui, porque achei que todo mundo aqui gosta de ajudar, especialmente quando eles sabem que você é sírio e não sabe falar português. Eles nos ajudavam e nos apoiavam. Então, pouco a pouco, e depois de muito sofrimento, a gente consegue falar um pouquinho, quando precisa.

O primeiro curso de português que eu fiz foi com um professor voluntário de origem libanesa, que ensinava vários sírios refugiados, aos sábados. Uns seis ou sete meses depois da minha chegada, soube, pelo padre da minha igreja, que havia aulas de português para os refugiados na Universidade Federal do Paraná. Alguns voluntários foram até a igreja, pegaram os nomes dos interessados e, depois de alguns dias, entraram em contato conosco. Foi assim que comecei as aulas de português na UFPR. Eram dois dias por semana e fiz mais ou menos um semestre, mas tive que parar para trabalhar na minha loja.

Mas, para meus dois filhos, foi muito mais fácil começar a falar. De repente, eles começaram a falar o português! Fiquei chocada, mas sempre a cabeça das crianças pode aprender mais rápido do que nossa cabeça. Uns dias depois, os dois estavam falando juntos o português, sem nenhuma palavra em árabe. Que raiva! $\mathrm{Na}$ verdade, não sei como me senti naquele dia, foi um sentimento estranho para mim e para meu marido: a gente quer aprender e falar o português, mas, ao mesmo tempo, a gente não quer que as crianças percam o árabe. Posso falar que foi difícil.

Quando decidi montar a loja, eu não tinha nenhuma experiência como vendedora e não falava muito português. Nós montamos a loja porque eu não conseguia a validação do meu diploma de professora de francês e porque eu precisava ganhar dinheiro para ajudar em casa. Andando na rua da minha casa, meu marido viu uma loja para vender. Entrou, falou com o dono e fez o negócio. Foi assim mesmo! Eu não sabia que era tão perigoso para uma mulher ficar sozinha em uma loja o dia inteiro. Passei por várias situações difíceis. Às vezes, teve uns momentos que a gente pensava em voltar 
REVISTA X, Curitiba, volume 13,n.1,p.6-8, 2018.

\section{Dossiê Especial: Português como Língua Adicional em contextos de minorias:}

(co)construindo sentidos a partir das margens

BIZON \& DINIZ (Orgs.)

mesmo, até com a guerra, porque era mais fácil para nós. A gente preferia a guerra a essa vida estranha no país estranho e com língua bem diferente.

Para não ficar o dia inteiro na loja sem fazer nada, decidi ir à Universidade para tentar validar o meu diploma. Lá eles pegaram todos os documentos necessários e me chamaram dois meses depois para uma prova escrita de francês e português, prova oral de francês e entrevista em português. Cada prova correspondia a uma fase da seleção. Se eu não passasse em uma, não poderia fazer a próxima. Eu passei em todas, mas, como eles acharam que a maneira de dar aula na Síria era diferente, tive que fazer disciplinas de didática e de conversação em francês na UFPR mesmo.

Quando eu fazia a disciplina de didática com a professora de francês, ela me avisou que tinha uma escola que precisava urgente de uma professora de francês. Fiz uma prova didática para ingressar em uma cooperativa de professores de línguas estrangeiras e comecei a dar aulas em setembro de 2017, depois de um pouco mais de dois anos no Brasil. Eu acho que foi importante fazer essas disciplinas, porque aprendi coisas novas e também conheci novas tecnologias para utilizar na sala de aula.

Para mim, era um sonho dar aula aqui no Brasil. Sempre quando eu vou à Universidade, eu me lembro daqueles dias difíceis em que eu me perguntava: “ $A i$, meu Deus, quando eu vou entrar como professora aqui?" Esse sonho eu já realizei. Todo dia que eu vou para a sala de aula, vivo momentos bons com meus alunos, quando eles dizem que gostam das minhas aulas, que não querem trocar de professora. Isso é o mais importante para mim. Eu penso também em fazer um mestrado e um doutorado quando terminar de revalidar meu diploma.

Mas agora que estou trabalhando naquilo que eu gosto de fazer, eu sinto que meus pés estão no chão, que estou mais tranquila e com a vida mais estabilizada. Sempre eu falo que tem que experimentar tudo na vida. Nós passamos por meses difíceis, mas ficamos mais fortes depois disso. Agora, vivaaaaa! Eu falo, escrevo e leio português!!! Não existe a palavra "impossível" na vida.

Graças à gente carinhosa e graças ao nosso esforço, estes dias difíceis já passaram, e nossa vida ficou muito mais fácil. Posso falar, no final, esta frase que eu gosto muito: "Ama sua vida em qualquer lugar, sofre, trabalha e tudo vai dar certo". 